Note

\title{
SCARIFICATION WITH SULPHURIC ACID OF Schizolobium amazonicum Huber ex Ducke SEEDS - FABACEAE
}

\author{
Eniel David Cruz ${ }^{1 *}$; José Edmar Urano de Carvalhoํㅜ Rafaela Josemara Barbosa Queiroz ${ }^{2}$ \\ ${ }^{1}$ Embrapa Amazônia Oriental, Trav. Dr. Enéas Pinheiro s/n, C.P. 48 - 66017-970 - Belém, PA - Brasil. \\ ${ }^{2}$ UNESP/FCAV - Programa de Pós-Graduação em Fisiologia Vegetal, Rod. Prof. Paulo Donatto Castellane, \\ s/n - 14884-900 - Jaboticabal, SP - Brasil. \\ *Corresponding author <eniel@cpatu.embrapa.br>
}

\begin{abstract}
Seed coat impermeability to water occurs in many species, including Schizolobium amazonicum Huber ex Ducke. To promote germination in seeds with coat impermeability the use of sulphuric acid $\left(\mathrm{H}_{2} \mathrm{SO}_{4}\right)$ is recommended. The objective of this study was to identify a better time for the scarification with sulphuric acid for $S$. amazonicum seeds. The effect of scarification with sulphuric acid for 20, 40 and 60 min on germination and speed germination was studied for seeds that were either sowed immediately after scarification or after a 24-hour period of immersion in water. Seeds were sown on a mix of sand and sawdust (1:1). The experimental design was completely randomized with four replications of 50 seeds. The statistical analysis of germination was carried out at six, nine, $12,15,18,21$ and 24 days after sowing, in a factorial scheme. For speed germination the means were compared by the Tukey test. There was an interaction between treatments to overcome dormancy and immersion time after scarification in most evaluations. Immersion in water accelerated the beginning of germination. All treatments to overcome dormancy promoted seed germination. However, scarification for $60 \mathrm{~min}$, showed better germination, $92 \%$ when immediately sown and $86.5 \%$ when sown after 24 hours. Speed germination index was highest for scarified seeds for 60 min followed by immersion in water. Scarification for $60 \mathrm{~min}$ was the most efficient treatment to promote germination in S. amazonicum seeds.
\end{abstract}

Key words: tropical species, Amazonian region, hard seed, seeds coat impermeability, physical dormancy

\section{ESCARIFICAÇÃO COM ÁCIDO SULFÚRICO DE SEMENTES DE Schizolobium amazonicum Huber ex Ducke - FABACEAE}

RESUMO: Impermeabilidade do tegumento da semente à água ocorre em muitas espécies, inclusive em Schizolobium amazonicum Huber ex Ducke. Para promover a germinação de sementes com tegumento impermeável um dos métodos recomendados é o uso de ácido sulfúrico $\left(\mathrm{H}_{2} \mathrm{SO}_{4}\right)$. O objetivo desse estudo foi identificar o melhor tempo de escarificação com ácido sulfúrico na superação da dormência em sementes de S. amazonicum, escarificadas durante 20,40 e 60 minutos. Parte das sementes foi semeada imediatamente após a escarificação e parte após 24 horas de imersão em água, em uma mistura de areia e serragem (1:1), onde foram quantificadas a porcentagem e a velocidade de germinação. O delineamento foi inteiramente casualizado com quatro repetições de 50 sementes. A análise estatística da germinação foi efetuada aos seis, nove, 12, 15, 18, 21 e 24 dias após a semeadura em esquema fatorial. Para a velocidade de germinação as médias foram comparadas pelo teste de Tukey. Foi observada interação entre tratamentos para superação da dormência e o tempo de imersão em água após a escarificação na maioria das avaliações. A imersão em água acelerou o início da germinação. Os tratamentos para superação da dormência promoveram a germinação das sementes, entretanto, as sementes escarificadas durante 60 minutos apresentaram melhor germinação, 92 e 86,5\% quando semeadas imediatamente e após 24 horas, respectivamente. O índice de velocidade de germinação foi superior nas sementes escarificadas durante 60 minutos e imersas em água. A escarificação durante 60 minutos constitui uma alternativa para redução da dormência das sementes.

Palavras-chave: espécie tropical, região Amazônica, semente dura, impermeabilidade do tegumento, dormência física 


\section{INTRODUCTION}

Seed coat impermeability to water, which causes physical dormancy, occurs in species of many families (Baskin \& Baskin, 1998; Copeland \& McDonald, 1995), causing slow and non-uniform germination (Cruz et al., 2001a). Physical dormancy often is broken by acid scarification (Fowler \& Bianchetti, 2000), and frequently concentrated sulphuric acid $\left(\mathrm{H}_{2} \mathrm{SO}_{4}\right)$ is used. However, the efficiency of this treatment varies with the concentration of the acid, plant species and treatment duration (Baskin \& Baskin, 1998; Sacheti \& Al-Rawahy, 1998). Seeds of Bowdichia virgiloides Kunth scarified for five minutes in sulphuric acid germinated $90 \%$ as compared to $21 \%$ of the control (Smiderle \& Souza, 2003). Cruz et al. (2001b) observed germination higher than $74 \%$ in Parkia nitida Miq. seeds scarified for 10, 20, 40 and 80 minutes while the control treatment presented only a germination of $1.5 \%$. Dialium guianeense seeds showed $74 \%$ of germination when scarified for $10 \mathrm{~min}$ utes and $1 \%$ in the control (MacDonald \& Omoruyi, 2003).

Schizolobium amazonicum Huber ex Ducke, Fabaceae, is native to the States of Pará and Amazonas (Ducke, 1949), is one of 350 tropical woody species presently exploited in the Brazilian Amazon (Martini et al., 1998). The species grows rapidly (Falesi \& Santos, 1996), and has been considered to be a promising species for reforestation in the Amazon region (Rosa \& Pinheiro, 2001).

For studying the germination of seeds of this species, Maruyama \& Ugamoto (1989) observed 28\% of germination with no treatments to overcome dormancy. The author reported that use of sulphuric acid during ten minutes did not promote germination, assuming that this treatment was not long enough to cause grooves on the coat to allow water absorption.

For commercial production of seedlings of species with impermeable seed coat, it is necessary to overcome dormancy to have a rapid and uniform germination Bianchetti \& Ramos (1982a). Thus, the objective of this study was to identify a better time for scarification with sulphuric acid to break dormancy in seeds of $S$. amazonicum. The hypothesis was that $S$. amazonicum seeds have higher germination when subjected to treatments with sulphuric acid to overcome dormancy.

\section{MATERIAL AND METHODS}

Schizolobium amazonicum seeds were collected in Belterra, PA, Brazil $\left(02^{\circ} 38^{\circ} \mathrm{S} ; 54^{\circ} 57^{\circ} \mathrm{W}\right)$. The experiment was carried out in Belém, PA, Brazil $\left(1^{\circ} 28^{\circ} \mathrm{S} ; 48^{\circ} 27^{\circ} \mathrm{W}\right)$ under room conditions (minimum and maximum temperatures of $22.9^{\circ} \mathrm{C}$ and $33.6^{\circ} \mathrm{C}$, minimum and maximum relative humidities of $79 \%$ and $89 \%$, and natural light). Seed moisture was evaluated in 25 individual seeds, at $105 \pm 3^{\circ} \mathrm{C}$ during 24 hours (Brasil, 1992).

The following treatments were evaluated: scarification in concentrated sulphuric acid $\left(\mathrm{H}_{2} \mathrm{SO}_{4}\right)$ for 20 minutes and immediate sowing $\left(\mathrm{T}_{2}\right)$; the same as $\mathrm{T}_{2}$ and sowing after 24 hours of immersion in water $\left(\mathrm{T}_{3}\right)$; scarification in concentrated sulphuric acid for 40 minutes and immediate sowing $\left(\mathrm{T}_{4}\right)$; the same as $\mathrm{T}_{4}$ and sowing after 24 hours of immersion in water $\left(\mathrm{T}_{5}\right)$; scarification in concentrated sulphuric acid for 60 minutes and immediate sowing $\left(\mathrm{T}_{6}\right)$; the same as $\mathrm{T}_{6}$ and sowing after 24 hours of immersion in water $\left(\mathrm{T}_{7}\right)$. These treatments were compared with a control treatment $\left(\mathrm{T}_{1}-\right.$ not scarified seeds). The seeds sown 24 hours after treatement remained in water under ambient room conditions. Three hundred $\mathrm{mL}$ of acid were used for 210 seeds. After scarification the seeds were washed in running water, during 30 minutes. During immersion in water for 24 hours, $400 \mathrm{~mL}$ of water were used for 210 seeds.

Seeds were sown at a depth of $0.5 \mathrm{~cm}$ in plastic recipients using a substrate containing sand and sawdust $(1: 1)$ previously sterilized in hot water $\left(100^{\circ} \mathrm{C}\right)$ for two hours. The substrate was irrigated every two days. Germination was checked every day, for 24 days. The percentage of abnormal seedlings, hard seeds and dead seeds was also quantified (Brasil, 1992); the number of days for germination, i.e., the number of elapsed days from sowing until germination of the first seed; and the speed germination index (Maguire, 1962). A seed was considered to be germinated when the first pair of true leaves appeared and the seedling had normal development and was healthy.

The experimental design was completely randomized with four replications of 50 seeds each. The data were subjected to the homogeneity of variance test (Bartlett test) according to Zar (1996), and the days to start germination and mean time of germination variables were transformed, using $\log (x+1)$. The statistical analysis of germination percentage was carried out at six, nine, 12, 15, 18, 21 and 24 days after sowing in a $3 \times 2$ factorial scheme (except control treatment). After last count, ANOVA was carried out for other variables and germination. Treatment means were compared by the Tukey's test $(P \leq 0.05)$. All analyses were performed by the software Statistica (Statsoft, 1999).

\section{RESULTS AND DISCUSSION}

For most evaluations an interaction was observed $(P \leq 0.05)$ between treatments to overcome dor- 
Table 1 - Cumulative germination at ix, nine, 12, 15, 18, 21 and 24 days after immediate sowing (IS) and sowing after 24 hours of immersion in water (S24), for Schizolobium amazonicum seeds.

\begin{tabular}{|c|c|c|c|}
\hline \multicolumn{4}{|c|}{ Six days } \\
\hline Treatments & IS & $\mathrm{S} 24$ & F test \\
\hline Scarification in $\mathrm{H}_{2} \mathrm{SO}_{4}$ for 20 minutes & $0.0 \mathrm{Aa}$ & $0.5 \mathrm{Ab}$ & - \\
\hline Scarification in $\mathrm{H}_{2} \mathrm{SO}_{4}$ for 40 minutes & $0.0 \mathrm{Ba}$ & $6.5 \mathrm{Ab}$ & - \\
\hline Scarification in $\mathrm{H}_{2} \mathrm{SO}_{4}$ for 60 minutes & $0.0 \mathrm{Ba}$ & $15.5 \mathrm{Aa}$ & - \\
\hline Treatments to overcome dormancy (A) & & & $10.2090 * *$ \\
\hline Immersion time after scarification (B) & & & $30.2239 * *$ \\
\hline $\mathrm{A} \times \mathrm{B}$ interaction & & & $10.2090 * *$ \\
\hline \multicolumn{4}{|c|}{ Nine days } \\
\hline Scarification in $\mathrm{H}_{2} \mathrm{SO}_{4}$ for 20 minutes & & $2.8 \mathrm{c}$ & - \\
\hline Scarification in $\mathrm{H}_{2} \mathrm{SO}_{4}$ for 40 minutes & & $20.5 \mathrm{~b}$ & - \\
\hline Scarification in $\mathrm{H}_{2} \mathrm{SO}_{4}$ for 60 minutes & & $49.0 \mathrm{a}$ & - \\
\hline Immediate sowing & & $16.0 \mathrm{~b}$ & - \\
\hline Sowing after 24-hour & & $32.2 \mathrm{a}$ & - \\
\hline Treatments to overcome dormancy (A) & & & $38.3715 * *$ \\
\hline Immersion time after scarification (B) & & & $13.8164 * *$ \\
\hline $\mathrm{A} \times \mathrm{B}$ interaction & & & $2.2305 \mathrm{~ns}$ \\
\hline \multicolumn{4}{|c|}{12 days } \\
\hline Scarification in $\mathrm{H}_{2} \mathrm{SO}_{4}$ for 20 minutes & & $9.2 \mathrm{c}$ & - \\
\hline Scarification in $\mathrm{H}_{2} \mathrm{SO}_{4}$ for 40 minutes & & $41.5 \mathrm{~b}$ & - \\
\hline Scarification in $\mathrm{H}_{2} \mathrm{SO}_{4}$ for 60 minutes & & $77.0 \mathrm{a}$ & - \\
\hline Immediate sowing & & $37.3 \mathrm{~b}$ & - \\
\hline Sowing after 24-hour & & $47.8 \mathrm{a}$ & - \\
\hline Treatments to overcome dormancy (A) & & & $95.0943 * *$ \\
\hline Immersion time after scarification (B) & & & $6.8470 * *$ \\
\hline $\mathrm{A} \times \mathrm{B}$ interaction & & & $2.4273 \mathrm{~ns}$ \\
\hline \multicolumn{4}{|c|}{15 days } \\
\hline Treatments & IS & S24 & F test \\
\hline Scarification in $\mathrm{H}_{2} \mathrm{SO}_{4}$ for 20 minutes & $17.0 \mathrm{Ac}$ & $16.0 \mathrm{Ac}$ & - \\
\hline Scarification in $\mathrm{H}_{2} \mathrm{SO}_{4}$ for 40 minutes & $40.0 \mathrm{Bb}$ & $59.5 \mathrm{Ab}$ & - \\
\hline Scarification in $\mathrm{H}_{2} \mathrm{SO}_{4}$ for 60 minutes & $88.0 \mathrm{Aa}$ & $85.5 \mathrm{Aa}$ & - \\
\hline Treatments to overcome dormancy (A) & & & $251.8853 * *$ \\
\hline Immersion time after scarification (B) & & & $4.3513^{*}$ \\
\hline $\mathrm{A} \times \mathrm{B}$ interaction & & & $7.7040 * *$ \\
\hline \multicolumn{4}{|c|}{18 days } \\
\hline Treatments & IS & S24 & F test \\
\hline Scarification in $\mathrm{H}_{2} \mathrm{SO}_{4}$ for 20 minutes & $18.5 \mathrm{Ac}$ & $19.5 \mathrm{Ac}$ & - \\
\hline Scarification in $\mathrm{H}_{2} \mathrm{SO}_{4}$ for 40 minutes & $43.5 \mathrm{Bb}$ & $62.5 \mathrm{Ab}$ & - \\
\hline Scarification in $\mathrm{H}_{2} \mathrm{SO}_{4}$ for 60 minutes & $89.0 \mathrm{Aa}$ & $86.0 \mathrm{Aa}$ & - \\
\hline
\end{tabular}


Table 2 - Continuation.

\begin{tabular}{|c|c|c|c|}
\hline \multicolumn{3}{|l|}{ Treatments to overcome dormancy (A) } & $293.2708 * *$ \\
\hline \multicolumn{3}{|l|}{ Immersion time after scarification (B) } & $6.0208^{*}$ \\
\hline \multicolumn{3}{|l|}{$\mathrm{A} \times \mathrm{B}$ interaction } & $8.5803 * *$ \\
\hline \multicolumn{4}{|c|}{21 days } \\
\hline Treatments & IS & $\mathrm{S} 24$ & F test \\
\hline Scarification in $\mathrm{H}_{2} \mathrm{SO}_{4}$ for 20 minutes & $21.5 \mathrm{Ac}$ & $21.5 \mathrm{Ac}$ & - \\
\hline Scarification in $\mathrm{H}_{2} \mathrm{SO}_{4}$ for 40 minutes & $47.0 \mathrm{Bb}$ & $68.0 \mathrm{Ab}$ & - \\
\hline Scarification in $\mathrm{H}_{2} \mathrm{SO}_{4}$ for 60 minutes & $91.5 \mathrm{Aa}$ & $86.5 \mathrm{Aa}$ & - \\
\hline Treatments to overcome dormancy (A) & & & $27.4797 * *$ \\
\hline Immersion time after scarification (B) & & & $5.1892 *$ \\
\hline $\mathrm{A} \times \mathrm{B}$ interaction & & & $11.5743 * *$ \\
\hline \multicolumn{4}{|c|}{24 days } \\
\hline Treatments & IS & $\mathrm{S} 24$ & F test \\
\hline Scarification in $\mathrm{H}_{2} \mathrm{SO}_{4}$ for 20 minutes & $25.5 \mathrm{Ac}$ & $23.5 \mathrm{Ac}$ & - \\
\hline Scarification in $\mathrm{H}_{2} \mathrm{SO}_{4}$ for 40 minutes & $48.5 \mathrm{Bb}$ & $70.0 \mathrm{Ab}$ & - \\
\hline Scarification in $\mathrm{H}_{2} \mathrm{SO}_{4}$ for 60 minutes & $92.0 \mathrm{Aa}$ & $86.5 \mathrm{Aa}$ & - \\
\hline Treatments to overcome dormancy (A) & & & $188.0364 * *$ \\
\hline Immersion time after scarification (B) & & & $2.9254 \mathrm{~ns}$ \\
\hline $\mathrm{A} \times \mathrm{B}$ interaction & & & $9.6530 * *$ \\
\hline
\end{tabular}

Means followed by the same upper case letter in the rows, and lower case letter in the columns, are not different by Tukey test $(P>0.05)$. ${ }^{*}$ and $* *$ indicate significance at $P \leq 0.01$ and $P \leq 0.05$, respectively. (ns) indicates not significant.

mancy and the immersion time of the seeds in water after scarification (Table 1). Immersion in water accelerated the beginning of germination, which started on the $6^{\text {th }}$ day after sowing for all treatments, and seeds scarified for 60 minutes presented a higher germination $(15.5 \%)$ (Table 1$)$. From the $15^{\text {th }}$ day on all treatments, both with immediate sowing and after 24 hours, had similar germination, except when seeds were scarified for 40 minutes. In this treatment immersion in water proportioned higher germination as compared to immediate sowing.

Analysis of variance detected differences $(P \leq 0.05)$ among treatments for all variables, except for dead seeds percentage (Table 2). All treatments to overcome dormancy promoted seed germination, however, scarification for 60 minutes had the highest germination (92\%) when immediately sown, and $86.5 \%$ when sown after 24 hours. Sulphuric acid has been reported as an efficient method to increase, accelerate and unify seed germination of species with seed impermeable coat (Bianchetti \& Ramos, 1981; Santarém \& Áquila, 1995; Alves et al., 2000; Araújo et al., 2000; Bruno et al., 2001; Cruz et al., 2001b; MacDonald \& Omoruyi, 2003). However, exposure time to acid is critical and needs to be quantified for each species, since seeds ex- posed to long period can be damaged (Schmidt, 2000). This fact was confirmed by Hermansen et al. (2000) for Dimorphandra mollis Benth. and MacDonald et al. (2002) for Tamarindus indica L. and Prosopis africana (Guill. \& Perr.) Taub. seeds.

The number of days elapsed from sowing to the beginning germination ranged from six to 9.25 but for scarified seed during 40 and 60 minutes, germination started before other treatments. Regarding the germination speed index, the highest performance was for scarified seeds for 60 minutes followed by immersion in water. Kondo (1993) showed that increases of the speed germination index in Lotus curniculatus var japonica Regel seeds scarified with sulphuric acid was proportional to the exposure time of seeds to acid. Similar results were reported by Delachiave \& Pinho (2003) with Senna occidentalis (L.) Link seeds.

The efficiency of sulphuric acid to overcome dormancy in water impermeable seed coats is measured by the reduction of hard seeds percentage. In the control treatment hard seed percentage was $97.5 \%$, while in scarified seeds during 60 minutes it ranged from 3 to $5 \%$.

Dead seeds and abnormal seedlings percentage was low for all treatments. However, in general, 
Table 2 - Germination (G), number of days to start germination (DSG), speed germination index (SGI), and hard seeds (HD), dead seeds (DS) and abnormal seedlings (AS), for Schizolobium amazonicum seeds.

\begin{tabular}{|c|c|c|c|c|c|c|}
\hline Treatments & G & DSG & SGI & HD & DS & AS \\
\hline & $\%$ & & & \multicolumn{3}{|c|}{ - } \\
\hline Control & $1.0 \mathrm{e}$ & $8.00 \mathrm{bcd}$ & $0.22 \mathrm{f}$ & $97.5 \mathrm{e}$ & $1.0 \mathrm{a}$ & $0.5 \mathrm{a}$ \\
\hline $\mathrm{H}_{2} \mathrm{SO}_{4}$ for $20^{\prime}$ and IS & $25.5 \mathrm{~d}$ & $9.25 \mathrm{~d}$ & $0.99 \mathrm{e}$ & $66.5 \mathrm{~d}$ & $1.5 \mathrm{a}$ & $6.5 \mathrm{~b}$ \\
\hline $\mathrm{H}_{2} \mathrm{SO}_{4}$ for $20^{\prime}$ and $\mathrm{S} 24$ & $23.5 \mathrm{~d}$ & $8.25 \mathrm{~cd}$ & $0.94 \mathrm{e}$ & $72.0 \mathrm{~d}$ & $3.0 \mathrm{a}$ & $1.5 \mathrm{a}$ \\
\hline $\mathrm{H}_{2} \mathrm{SO}_{4}$ for $40^{\prime}$ and IS & $48.5 \mathrm{c}$ & $7.75 \mathrm{abcd}$ & $2.13 \mathrm{~d}$ & $46.0 \mathrm{c}$ & $3.0 \mathrm{a}$ & $2.5 \mathrm{a}$ \\
\hline $\mathrm{H}_{2} \mathrm{SO}_{4}$ for $40^{\prime}$ and $\mathrm{S} 24$ & $70.0 \mathrm{~b}$ & $6.25 \mathrm{ab}$ & $3.60 \mathrm{c}$ & $22.0 \mathrm{~b}$ & $5.0 \mathrm{a}$ & $3.0 \mathrm{a}$ \\
\hline $\mathrm{H}_{2} \mathrm{SO}_{4}$ for $60^{\prime}$ and IS & $92.0 \mathrm{a}$ & $7.00 \mathrm{abc}$ & $4.58 \mathrm{~b}$ & $3.0 \mathrm{a}$ & $2.0 \mathrm{a}$ & $3.0 \mathrm{a}$ \\
\hline $\mathrm{H}_{2} \mathrm{SO}_{4}$ for $60^{\prime}$ and $\mathrm{S} 24$ & $86.5 \mathrm{a}$ & $6.00 \mathrm{a}$ & $5.51 \mathrm{a}$ & $5.0 \mathrm{a}$ & $5.0 \mathrm{a}$ & $3.5 \mathrm{ab}$ \\
\hline
\end{tabular}

Means followed by the same letter in the columns are not different by Tukey test $(P>0.05)$. IS and S24 indicate immediate sowing and sowing after 24 hours, respectively; seed moisture $=11.3 \% \pm 2.2$.

the increase of immersion time in acid caused only a small decrease in hard seeds and increase in abnormal seedlings percentages, probably because hardness of coats varied among seeds of the same sample. Bianchetti \& Ramos (1982b) also observed an increase in abnormal seedlings percentage for Pelthoporium dubium (Spreng.) Taub. with an exposure time of seeds to acid changing from two to eight minutes.

\section{CONCLUSION}

Scarification in sulphuric acid for 60 minutes is an efficient treatment to promote germination in $S$. amazonicum seeds.

\section{AKNOWLEDGEMENTS}

To Moacyr B. Dias Filho for suggestions on the manuscript.

\section{REFERENCES}

ALVES, M. da C.S.; MEDEIROS FILHO, S.; ANDRADE NETO, M.; TEÓFILO, E.M. Superação da dormência em sementes de Bauhinia monandra Britt. e Bauhinia ungulata L. - Caesalpinoideae. Revista Brasileira de Sementes, v.22, p.139-144, 2000.

ARAÚJO, E.F.; ARAÚJO, R.F.; SILVA, R.F. da; GOMES, J.M. Avaliação de diferentes métodos de escarificação das sementes e frutos de Stylosanthes viscosa Sw. Revista Brasileira de Sementes, v.22, p. 18-22, 2000.

BASKIN, C.C.; BASKIN, J.J. Seeds: ecology, biogeography, and evolution of dormancy and germination. San Diego: Academic Press, 1998. cap.6, p.101-132: Germination ecology of seeds with physical dormancy.

BIANCHETTI, A.; RAMOS, A. Quebra de dormência de sementes de canafístula (Peltophorum dubium (Spreng.) Taubert: resultados preliminares. Boletim de Pesquisa Florestal, n.3, p.87-95, 1981.

BIANCHETTI, A.; RAMOS, A. Comparação de tratamentos para superar a dormência de sementes de acácia-negra (Acacia mearnsii De Wild.). Boletim de Pesquisa Florestal, n.4, p.101-111, 1982a.

BIANCHETTI, A.; RAMOS, A. Comparação de tratamentos para superar a dormência de sementes de canafístula (Petophorum dubium (Spreng) Taubert). Boletim de Pesquisa Florestal, n.4, p.91-99, 1982b.

BRASIL. Ministério da Agricultura e Reforma Agrária. Regras para análise de sementes. Brasília: SNDA/DNDV/CLAV, 1992. 365p.
BRUNO, R.L.A.; ALVES, E.U.; OLIVEIRA, A.P.; PAULA, R.C. Tratamentos pré-germinativos para superar a dormência de sementes de Mimosa caesalpiniaefolia Benth. Revista Brasileira de Sementes, v.23, p.136-143, 2001.

COPELAND, L.O.; MCDONALD, M.B. Principles of seed science and technology. New York: Chapman \& Hall, 1995. cap.6, p.127-152: Seed dormancy.

CRUZ, E.D.; MARTINS, F. de O.; CARVALHO, J.E.U. de. Biometria de frutos e sementes e germinação de jatobá-curuba (Hymenaea intermedia Ducke, Leguminosae - Caesalpinioideae). Revista Brasileira de Botânica, v.24, p.161-165, 2001a.

CRUZ, E.D.; CARVALHO, J.E.U. de; LEÃO, N.V.M. Métodos para superação da dormência e biometria de frutos e sementes de Parkia nitida Miquel. (Leguminosae - Mimosoideae). Acta Amazônica, v.31, p.167-177, 2001b.

DELACHIAVE, M.E.A.; PINHO, S.Z. de. Scarification, temperature and light in germination of Senna occidentalis seed (Caesalpinaceae). Seed Science and Technology, v.31, 225-230, 2003.

DUCKE, A. Notas sobre a flora neotrópica - II: as leguminosas da Amazônia Brasileira. Belém: Instituto Agronômico do Norte, 1949. 247p. (Boletim Técnico, 18).

FALESI, I.C.; SANTOS, J.C. dos. Produção de mudas de paricá Schizolobium amazonicum Huber ex Ducke. Belém: FCAP, Serviço de Documentação e Informação. 1996, 16p. (Informe Técnico, 20).

FOWLER, J.A.P.; BIANCHETTI, A. Dormência em sementes florestais. Colombo: Embrapa Florestas, 2000. 21p. (Documentos, 40).

HERMANSEN, L.A.; DURYEA, M.L.; WEST, S.H.; WHITE, T.L.; MALAVASE, M.M. Pretreatments to overcome seed coat dormancy in Dimorphandra mollis. Seed Science and Technology, v.28, p.581595,2000

KONDO, T. Promotion of hard-seed germination in Lotus corniculatus var. japonica for use in amenity grasslands. Seed Science and Technology, v.21, p.611-619, 1993.

MACDONALD, I.; OMORUYI, O. Effect of seed pre-treatment on germination of two surface types of Dialium guianeense. Seed Technology, v.25, p.41-44, 2003.

MACDONALD, I.; OMONHINMIN, A.C.; OGBOGHODO, I.A. Germination ecology of two tree species, Tamarindus indica and Prosopis africana. Seed Technology, v.24, p.103-107, 2002.

MAGUIRE, J.D. Speed of germination-aid in relation evaluation for seedling emergence vigor. Crop Science, v.2, p.176-177, 1962.

MARTINI, A.; ROSA, N. de A.; UHL, C. Espécies de árvores potencialmente ameaçadas pela atividade madeireira na Amazônia. Belém: IMAZON, 1998. 34p. (Série Amazônia, 11).

MARUYAMA, E.; UGAMOTO, M. Treatments for promoting germination of Parkia oppositifolia Benth. and Schizolobium amazonicum Huber. Journal of the Japanese Forestry Society, v.71, p.209-211, 1989. 
ROSA, L. dos S.; PINHEIRO, K.A.O. Propagação vegetativa de estacas de paricá (Schizolobium amazonicum Huber ex Ducke) obtidas de material juvenil e imersas em ácido indol-3-butírico. Revista de Ciências Agrárias, n.35, p.79-88, 2001.

SACHETI, U.; AL-RAWAHY, S.H. The effects of various treatments on the germination of important leguminous shrub-tree species on the Sultanate of Oman. Seed Science and Technology, v.26, p.691699, 1998.

SANTARÉM, E.R.; AQUILA, M.E.A. Influência de métodos de superação de dormência e do armazenamento na germinação de sementes de Senna macranthera (Colladon) Irwin \& Barneby (Leguminosae). Revista Brasileira de Sementes, v.17, p.205-209, 1995.
SCHMIDT, L. Dormancy and pretreatment. In: OLESEN, K. (Ed.). Guide to handling of tropical and subtropical forest seeds. Humlebaek: Danida Forest Seed Centre, 2000. cap.9, p.263-303

SMIDERLE, O.J.; SOUZA, R. de C.P. de. Dormência em sementes de paricarana (Bowdichia virgiloides Kunth - Fabaceae - Paplionaceae). Revista Brasileira de Sementes, v.25, p.48-52, 2003.

STATSOFT. Statistica for windows. General conventions and statistics. 2.ed. Tulsa, Statsoft, 1999.

ZAR, J.H. Biostatistical analysis. New Jersey: Prentice Hall, 1996. 662p.

Received August 16, 2005

Accepted March 23, 2007 